\title{
Estimating the potential for conservation of electrical energy in the residential sector of Manaus- AM/Brazil, from the power quality evaluation
}

\author{
CARTAXO, Elizabeth; VALOIS, Ilsa; DAMASCENO, Arnilson; COSTA, Márcia \\ ${ }^{1}$ Núcleo Interdisciplinar de Energia e Meio Ambiente-NIEMA \\ Faculdade de Tecnologia - Universidade Federal do Amazonas-UFAM \\ Email: ecartaxo@ufam.edu.br
}

\begin{abstract}
This work is a study of electricity supplied to residential customers in the city of Manaus-AM/Brazil. We selected three residential consumers with profiles of different loads, of which were collected data concerning the quality of the energy used in homes. The research made use of a tool, the analyser of power quality, KEW 6310. On the basis of procedures for electricity distribution by ANEEL, which provides for minimum requirements for energy (voltage and frequency) we compared the results of the evaluation in selected consumers, where, from the point of view of the network voltage and frequency, the minimum levels laid down by ANEEL are serviced. However, are observed significant levels of harmonic distortion of currents on consumers in study. Finally, it is shown the impact caused by these distortions in the elevation of consumption and the estimation of energy conservation in the residential sector.
\end{abstract}

\section{Key words}

Energy Conservation, Quality of electrical energy, residential consumers.

\section{Introduction}

The use of electric energy in low tension in the city of Manaus occurs through consumer units (households, commerce, small industries and others). This input is available today by the concessionaire Eletrobras-Amazon Energy. It increases the population quality of life and enables the growth and the economic development of the city of Manaus and other municipalities in the State.

However, over the years, as consumers were becoming more technologically sophisticated, several factors are being questioned regarding the electricity they provided. Not only in relation to indexes of reliability in the supply, i.e. the quality of the energy distribution service, but also on the quality of the product, "supplied electricity" to such consumers.

It has been noted several adverse events to the residential consumer, when he uses the electrical power, such as electronic appliances burning for no apparent reason, light flickering, interference, increase in electrical energy consumption which is measured, apart from interruptions in the supply of the service.
This paper aims to analyse the quality of the electricity supplied to residential consumers of electricity in Manaus city.

\section{Manaus residential consumer profile}

The electric energy consumption of the residential class in the year 2010 accounted for $23 \%$ of total energy consumption in the city, namely $933 \mathrm{GWh}$ of electricity. This means an increase of $5.58 \%$ in average residential consumption compared to the previous year $(884 \mathrm{GWh})$.

The residential subclass, target of this study, in the year of 2010, represented 409,291 consumer units. A research, coordinated by Eletrobras, through the PROCEL (figure 1 ), showed the distribution of electricity consumption in the residential class, related to the use of appliances.

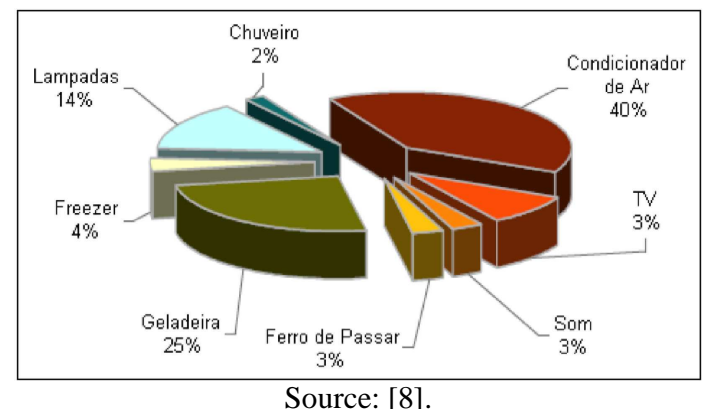

Figure 1: Participation by equipment in residential consumption.

The typical residential consumer of electricity in Manaus city presents itself with a predominance of consumption in HVAC equipment (air conditioners), and that fact is justified due to the hot climate of the region. It is noteworthy the significant contribution of lighting during the night and the constant consumption in refrigerators and freezers which run 24 hours a day. The contribution of the televisions is also significant, especially at night.

\section{Conservation and Energy Efficiency in the Residential Sector}

"Energy conservation as a concept socioeconomic both in end use as in the power supply, is supported by two tools to achieve its goal: changing habits and energy efficiency 
[6], both very well related when it comes to reducing waste.

The energetic efficiency measures adopted worldwide have been applied since the seventies, motivated by the oil crisis. In Brazil, the first action of the federal Government in relation to the energy conservation took place in 1981 , through the Conserve Program, which aimed to stimulate conservation and replacement of fuel oil used in the industry in order to promote energy efficiency, development of more energy-efficient products and processes, stimulating the replacement of imported energy.

If the current structure of the energy use is maintained, we will need to supply, in 2015, around $780 \mathrm{TWh} / \mathrm{year}$. Decreasing the waste, it is estimated an annual reduction of up to $130 \mathrm{TWh}$ - approximate production of two Itaipu plants.

\section{Eletric Power Quality Disturbances}

The power quality, necessary for the final use, is subject to the various stages of the electric power system, ranging from the generation, transmission and distribution, until the final energy consumption. In essence, the power quality term is used to characterize any variation of amplitude, frequency and/or any distortion of waveform of electrical magnitudes, whether in terms of a transitional or permanent electrical system which can cause the failure or malfunction of electrical equipments [6].

According to [2], the definition of problems related to quality of electrical energy is: any problem of energy manifested in the voltage, current or frequency variations resulting in failure or improper operation of consumer equipment

We can tell that quality of energy can present different definitions according to the needs and desires of each group. In the case of utilities, energy quality is treated as an indicator of reliability of electrical supply being this indicator evaluated through of the analysis and statistics. The equipment manufacturers define quality of energy as electrical energy with levels of voltage and frequency within the parameters with which the equipment still working satisfactorily. For the final users, power quality is associated with continuity of service uninterrupted supply, allowing to use whenever they wish

Regardless of the definition applied to the power quality, it is well known that the poor quality power is a concern in all segments involved with electricity and it needs to be treated in order to reduce their effects on any group to be considered.

\section{A. Ideal conditions for operating an electrical system}

1) Sinusoidal waveform: The sine function ensures the reversibility of electromagnetic conversion process, associated with the Faraday induction law, preserving the flow waveforms and voltage. Mathematically the sinusoidal voltage is characterized as in equation.

$$
\mathrm{v}(\mathrm{t})=\mathrm{A} \sin \left(2 \prod \mathrm{ft}+\varphi\right)
$$

Where:

A: sine wave amplitude (V); $\mathrm{f}$ : wave frequency $(\mathrm{Hz})$;

$\theta$ : phase angle relative to the temporal reference (rad)

2) Constant amplitude: The amplitude of the voltage determines the required level to the isolation and the level of current for a given power or for a given impedance. Therefore, for certain kind of insulation, is the amplitude of the constant voltage that ensures the desired power to loads of the passive constant impedance.

3) Constant frequency: There is a need for a continuous and rigorous frequency control to keep the system operating in stable conditions, as it is the frequency of the voltage that determines the balance between big powers generated and consumed by the loads, the stability of the operation of synchronous generators and the synchronism between the various interlinked generators.

4) Phase balanced: In three phase systems, in addition to the features of waveform, the power must be distributed equally among the phases, to ensure a balanced system, where for each stage the loads must have the same electrical and magnetic characteristics and strains the same amplitudes and lags. These conditions are satisfied for the voltages given in the following equations.

$$
\begin{aligned}
& \mathrm{va}(\mathrm{t})=A \sin \left(2 \prod \mathrm{ft}+\varphi\right) \\
& \mathrm{vb}(\mathrm{t})=A \sin \left(2 \prod \mathrm{ft}+\varphi-2 \prod / 3\right) \\
& \mathrm{vc}(\mathrm{t})=A \sin \left(2 \prod \mathrm{ft}+\varphi+2 \prod / 3\right)
\end{aligned}
$$

\section{B. Variations of short duration voltage}

Voltage variation is a modification of the voltage value, originally set as the default, also called nominal value, being possible the variation of this value to larger or smaller values. However, all voltage variation should be integrated into one unit of time that defines the type of variation of tension. The short duration voltage variation is characterized by the phenomenon of increase or reduction of voltage in relation to the nominal voltage of the network during a period between half cycle and one minute. When it comes to a voltage sags, short-term variation is known as DIP or SAG, and when the variation of short-lived pose as high voltage, is commonly called a SURGE or SWELL

\section{Long duration voltage variations}

According to [6], is the variation of tension that occurs for a period greater than one minute. Such variations may be present in three ways: Under voltage, over voltage, and Sustained interruption.

\section{Voltage unbalance}

The voltage imbalance is unequal variation in the amplitude of three-phase electrical system voltages. Power imbalances are common in three-phase power distribution systems, however, can occur in the internal electrical installations.

\section{E. Voltage fluctuation}

The fluctuation of voltage, also known as flicker, is the systematic variation of the effective value of supply 
voltage within the range of 0.95 and $1.05 \mathrm{pu}$. Is caused by variations of load, such as arc furnaces, elevators, pumps and compressors.

\section{F. Impulsive and Oscillatory Transient}

As [2], transients are electromagnetic phenomena arising from sudden changes in the operating conditions of the electrical system. There are two transient categories: Impulsive that occur due to lightning and Oscillatory caused by switching of loads.

\section{G. Waveform distortion}

A waveform distortion is a deviation, in permanent regime, purely sinusoidal waveform, in fundamental frequency, and is characterized by its spectral content. The main distortions in the waveform can be: sine wave with continuous voltage level; sine wave with harmonic distortion; sine wave with inter harmonics - Inter harmonics are voltages or currents with frequencies not integer multiples of the fundamental frequency of the system; waveform notching Switching clippings also known as notching, are successive and abrupt voltage transitions between different levels, being a periodic voltage disturbance; and, sine wave with noise - Noise is defined as an unwanted electrical signal, containing a wide spectral range with frequencies less than $200 \mathrm{kHz}$.

\section{H. Variation in system frequency}

Changes in frequency of an electric system are defined as deviations in the value of the fundamental frequency of the system (in the case of Brazil $60 \mathrm{~Hz}$ ).

\section{Quality of Service}

In addition to the indicators of product "quality electric energy", ANEEL stipulates quality indicators of energy supply service. They are: Duration of Interruptions per Consumer Unit (DEC); Frequency of Interruptions per Consumer Unit (FEC); Individual outage duration by consumer (DIC); Individual Outage frequency per consumer (FIC); e Maximum duration of Continuous Interruption per consumer (DMIC). Table 01 shows the results of DEC and FEC of the Eletrobras Amazon Energy obtained in the year of 2010 .

Table I. - Power quality indicators 2010-Manaus

\begin{tabular}{|l|l|c|c|}
\hline Indicator & \multicolumn{1}{|c|}{ Unit } & Meta ANEEL & Done \\
\hline FEC & Number of interrup/year & 24.82 & 28.94 \\
\hline DEC & hours/yaers & 24.89 & 47.36 \\
\hline
\end{tabular}

\section{METHODOLOGY}

The Brazilian legislation that deals with the power quality was prepared by the national electric energy agencyANEEL, in its document - Procedures for distribution of electricity in the "Power quality" [1]. Such regulation is not yet completely defined, however, these procedures were recently reviewed as the normative resolution $\mathrm{n}^{\circ}$ 469/2011 by ANEEL, being in force since January 1, 2012.

This work followed the recommendations of Prodist-8 module in carrying out observation and monitoring the quality of the electricity supplied in the city, and in the identification of the main disorders that cause waste of electricity. Quality measurements were made for 3 types of residential-class consumers, more specifically of the residential subclass-I, depending on the type of load installed and its connection to the system, as described in standard [5].
A. To consumer with installed load up to $7,5 \mathrm{~kW}$, the connection type will be single-phase
B. To consumer with installed load $7,5 \mathrm{~kW}$ up to $15 \mathrm{~kW}$, the connection type will be biphasic
C. To consumer with installed load $7,5 \mathrm{~kW}$ to $38 \mathrm{~kW}$, the connection type will be three-phase

They were made observations and measurements of the electric power supplied to each of the three types of selected consumers, according to the profile shown above. The choice of each one of these was random, being chosen only one of each track of installed power. It was provided in punctual way a small diagnosis of power quality, but considering that the system of distribution of electricity in the city of Manaus operates in "ring", it is assumed that the disturbances presented in the network, extend for the entire system though mitigated. Additionally, residential consumers who have loads approximate, also have the same consumption profile, as explained by the "research possession of equipment and usage habits of the residential class, the report of the North" [8].

When we consider consumers with different loads we can get the potential waste of each one, taking into consideration the installed load. Thus, it is possible to know, for example, what kinds of disturbances are perceived in consumers with different load profile. Table 2 show each consumer selected with their respective loads installed in each one of them.

Table 2 - Installed load on consumer 1, 2 and 3.

\begin{tabular}{|l|c|c|c|c|c|c|}
\hline \multirow{2}{*}{ Eletrical Equipment } & \multicolumn{3}{|c|}{ Qt. } & \multicolumn{3}{c|}{ Power (W) } \\
\cline { 2 - 7 } & C1 & C2 & C3 & C1 & C2 & C3 \\
\hline Compact fluorescente lamps 18W & 2 & 4 & 5 & 30 & 60 & 75 \\
\hline 50W dicroic lamps & - & - & 10 & - & - & 500 \\
\hline 20W tubular fluorescente lamps & 8 & 6 & 8 & 160 & 120 & 160 \\
\hline 16W tubular fluorescente lamps & - & - & 10 & - & - & 160 \\
\hline TV 32" LCD 140W & 1 & 1 & 1 & 180 & 140 & 140 \\
\hline TV 42" LCD 190W & - & 1 & 1 & - & 120 & 190 \\
\hline TV 40" LED 120W & - & - & 1 & - & - & 120 \\
\hline Computer with printer 180W & - & 1 & 2 & - & 170 & 360 \\
\hline Video Game 50W & - & - & 1 & - & - & 50 \\
\hline DVD player 40W & - & 1 & 1 & - & 40 & 40 \\
\hline Antenna Receiver 30W & - & - & 1 & - & - & 30 \\
\hline Automatic Electric Iron & - & - & 1 & - & - & 1100 \\
\hline Microwave Oven & - & - & 1 & - & - & 1000 \\
\hline Hair Dryer & - & 1 & 1 & - & - & 1000 \\
\hline Blender & 1 & 1 & 1 & 120 & 100 & 120 \\
\hline Cooler & 1 & 1 & 1 & 120 & 100 & 200 \\
\hline Fan & 2 & 3 & - & 140 & 210 & - \\
\hline Air Conditioner & 1 & 3 & 3 & 820 & 2690 & 3200 \\
\hline
\end{tabular}

The power quality Analyzer used to monitor is a parser KEW 6310, Kyoritsu Electrical Instruments manufacturer, with calibration certificate $n^{\circ}$ GS-075 manufacturer's own.

\section{Results}

The voltage monitoring in permanent regime was made by reading the effective values of voltage, in consecutive intervals of 10 minutes for a week, a total of 1.008 valid readings. After obtaining the set of readings were found 
the index of duration of the transgression, to Precarious voltage (DRP), and the index for Critical voltage (DRC), according to the following equations.

$\mathrm{DRP}=(n l p / 1008) 100 \%$

$\mathrm{DRC}=(n l c / 1008) 100 \%$

Where:

nlp: number readings in the range of precarious tension; nlc: number readings in critical voltage range.

The following figures show the results of monitoring of voltage in the selected residential consumers, for a week. In these graphs we can see that the voltage variation remained almost entirely within the range for voltage in permanent regime defined by ANEEL.

Figure 2 a shows that in the monitoring of Consumer 1 , the voltage in permanent regime remains steady in the range of proper voltage. The maximum value of registered neutral-phase voltage was $130.5 \mathrm{~V}$ and the minimum value of $119.2 \mathrm{~V}$, with an average value of $125.24 \mathrm{~V}$ during the monitoring period.
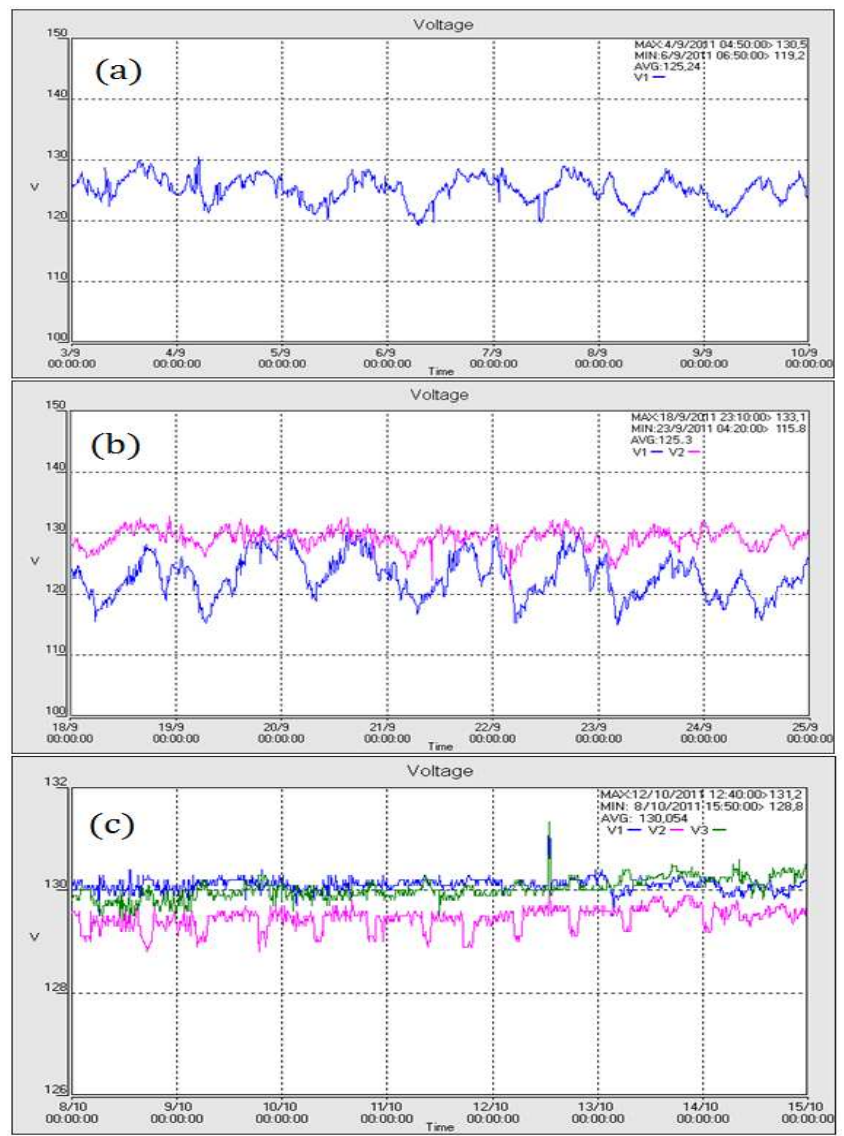

Fig. 2 - (a) Single-phase, (b) Two-phase and (c) three-phase obtained respectively on Consumer-1, 2 and 3.

The voltage observed in Consumer 2 also remained within the proper voltage levels, although it was registered a maximum value of $133.1 \mathrm{~V}$ and minimum of $115.8 \mathrm{~V}$ (Figure 2b).

The voltage shown in consumer- 3 monitoring presented within the proper voltage level by ANEEL, where the recorded voltage maximum value was $131.2 \mathrm{~V}$ and minimum of $128.8 \mathrm{~V}$. The average voltage during the observation was of 130.05 V. A Figure 2c show a sample waveform during the monitoring.
As established in the item 2.11 of the [5], the maximum voltage levels, (precarious duration-DRP and duration criticism-CKD), should be of $3 \%$ and $0.5 \%$, respectively. However, taking into account that, in the measurements was not observed voltage at critical level, and the voltage reached a precarious level only once in Consumer-2, the maximum duration indices of transgression, to Critical and Precarious voltage, DRP and CKD, respectively, were within the levels stipulated by ANEEL.

The item 8, module- 8 [5], provides that the distribution systems operating at $60 \mathrm{~Hz}$ frequency should, in normal operating conditions and in permanent regime, maintain the frequency between $59.9 \mathrm{~Hz}$ and $60.1 \mathrm{~Hz}$. However, the same document admits the track between $59.5 \mathrm{~Hz}$ to $60.5 \mathrm{~Hz}$, as acceptable. The performed measurements on consumers show that the frequency of voltage supply remained within the limits laid down in the [5].

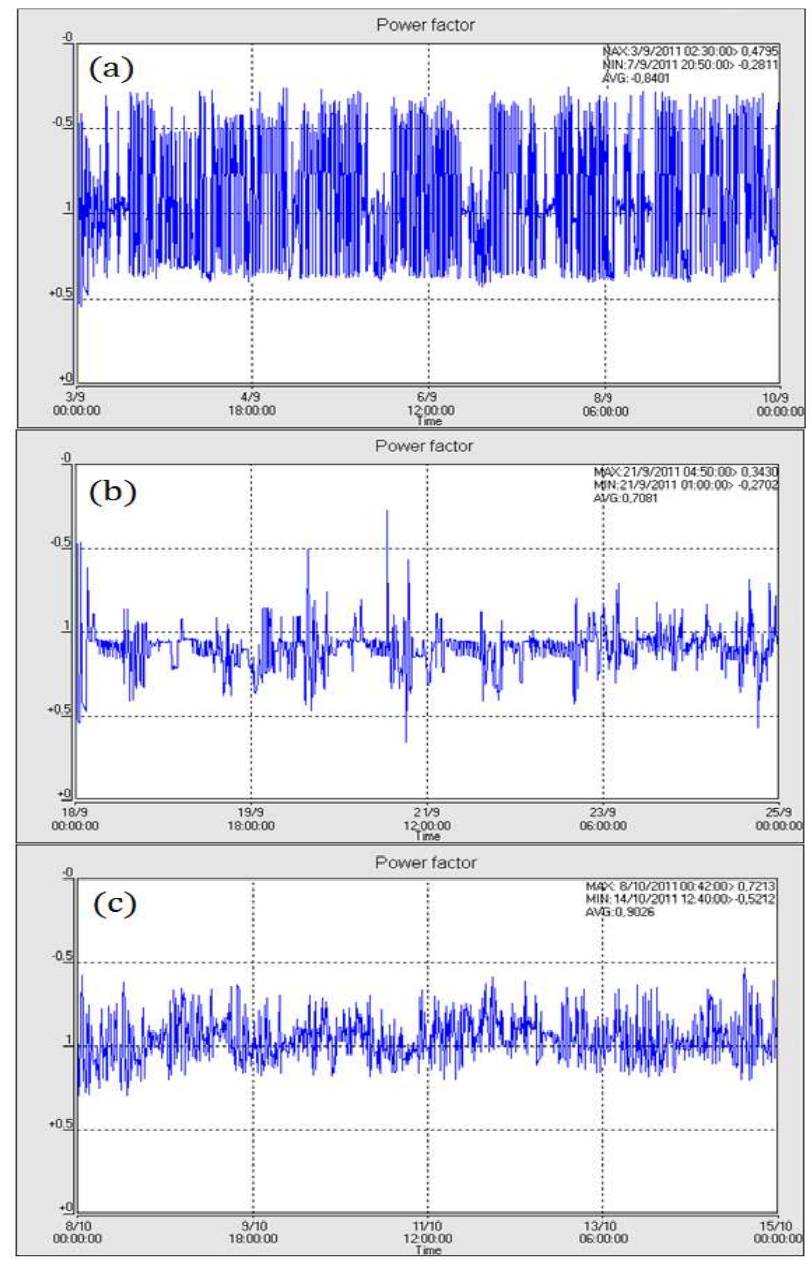

Fig. 3. Consumer-1-3 (a, b, c) frequency monitoring.

The power factor, in all cases, was presented outside the levels referred to in [5]. This fact was expected because the power factor is a quantity that depends not only on the voltage of the supply, but also on the current absorbed by the load of consumers.

Harmonic distortions are phenomena associated with deformations in the waveforms of currents and voltages, in relation to fundamental frequency sine wave. When the values of the initial sample of voltage harmonic spectrum were compared with reference values of ANEEL we noted that all levels of harmonic distortion, 
and individual totals remained within the standards of ANEEL. The graphs shown provide a Total Harmonic Distortion of the voltage at studied consumers. In the Consumer-1 the highest level of Total Harmonic Distortion (THD) during the period of observation was of $1.5 \%$ for the voltage in permanent regime. The highest level of Total Harmonic Distortion of the others consumers (2 and 3) was $2.3 \%$ and $1.4 \%$, respectively.

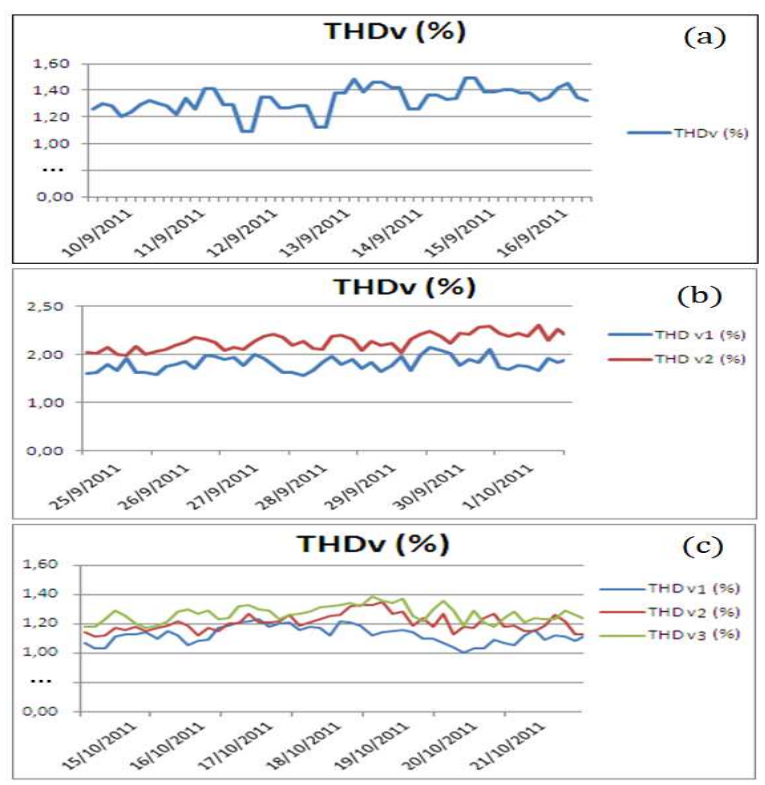

Fig. 4. Voltage Harmonic Distortion THDv Consumers 1-3 (a-c).

The voltage imbalance is the phenomenon associated with the changes in the patterns of three-phase distribution system. The reference value for the voltage imbalance factor in busbar in the distribution system must be equal to or less than $2 \%$. In the case of the consumer-3, the one with three-phase connection, the voltage imbalance at the beginning of observation was of $1.33 \%$. During the verification of the quality of the power supplied, it was observed like supply of electricity per example, remained within the limits set by ANEEL. In the measurements were not recorded variations of short duration voltage for the instrument.

Were also collected current data of consumption.

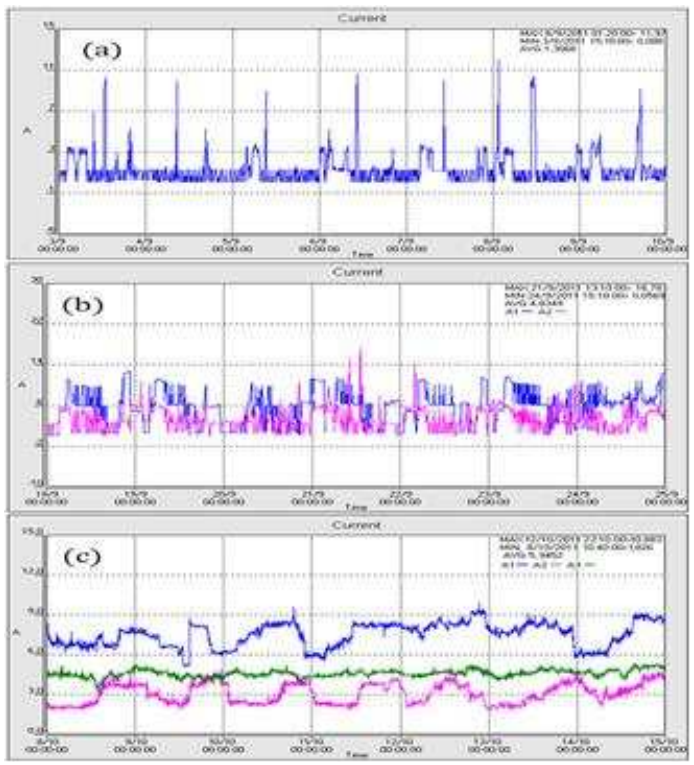

Fig. 5. Current in Consumer 1-3.
The average current in studied consumers was 1,30A, 4,83A, and 5,94A respectively.

The figures 6 a-c present the profile of Current Total Harmonic Distortion (THDi) on each consumer.

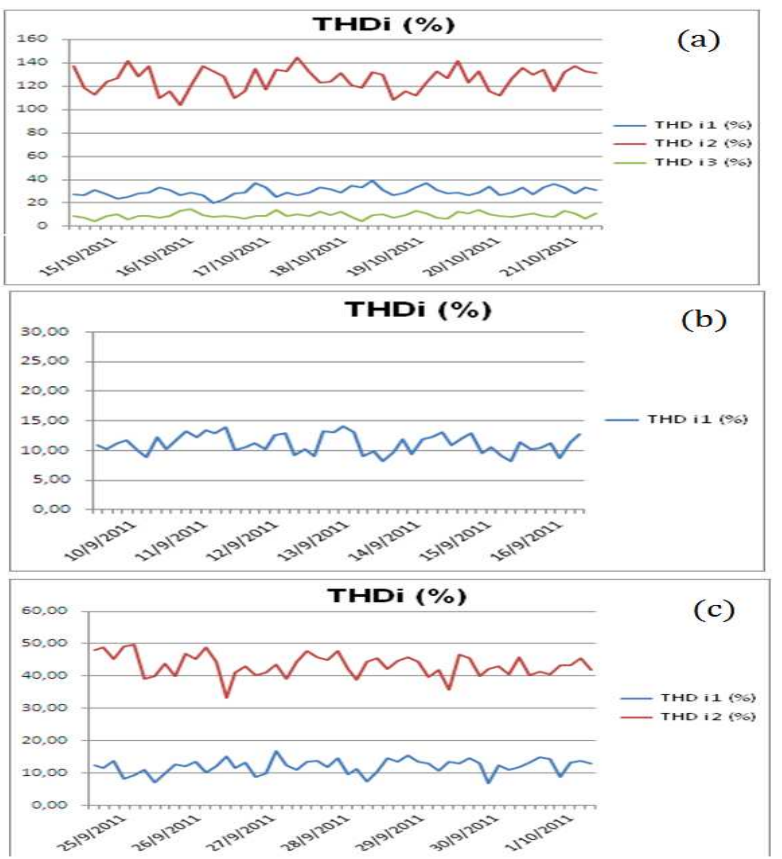

Fig.6. Harmonic distortion of Current THDi on Consumers 1-3

The presence of harmonic currents on consumers contributes, significantly, to the increase of the electrical energy consumption. Based on data from [4] and using the calculations of interpolation of values to get an approximate percentage of current increase in chains of consumers studied (due to the presence of THDi), the following results werw found.

Table 3 - Current without losses by THDi

\begin{tabular}{|c|c|c|c|c|c|c|c|c|c|c|c|c|}
\hline \multicolumn{4}{|c|}{$\begin{array}{c}\text { Average } \\
\text { Current (A) }\end{array}$} & \multicolumn{4}{|c|}{ THDi (\%) } & \multicolumn{3}{c|}{$\begin{array}{c}\text { Current } \\
\text { increase } \\
\text { about THDi } \\
(\%)\end{array}$} & \multicolumn{2}{c|}{$\begin{array}{c}\text { Current } \\
\text { without } \\
\text { losses by } \\
\text { THDi (A) }\end{array}$} \\
\hline $\boldsymbol{\varphi}$ & A & B & C & A & B & C & A & B & C & A & B & C \\
\hline $\mathbf{1}$ & 1,3 & - & - & 11,2 & - & - & 0,7 & - & - & 1,3 & - & - \\
\hline $\mathbf{2}$ & 6,2 & 3,3 & - & 12,1 & 43,4 & - & 0,9 & 9,4 & - & 6,2 & 3,2 & - \\
\hline $\mathbf{3}$ & 8,1 & 3,3 & 4,78 & 29,8 & 125,9 & 9,5 & 4,4 & 60,8 & 0,5 & 7,7 & 2,0 & 4,7 \\
\hline
\end{tabular}

Table 4 shows the power consumed by the loads, considering the current obtained in the enerty monitoring. Otherwise, the table 5 shows the power that would be consumed in the studied cases, not considering the losses by harmonic current distortion (THDi).

Table 4 - Power consumption due to losses THDi

\begin{tabular}{|c|c|c|c|c|c|c|c|c|c|c|}
\hline & Me & $\begin{array}{l}\text { a Vo } \\
\text { (V) }\end{array}$ & ge & & Ged & & & & & $\begin{array}{l}\text { Total } \\
\text { Power }\end{array}$ \\
\hline$\varphi$ & $\mathbf{A}$ & B & C & $\mathbf{A}$ & B & C & $\mathbf{A}$ & B & C & \\
\hline 1 & 125,2 & - & - & 1,3 & - & - & 137 & - & - & 13 \\
\hline 2 & 124,2 & 0 & - & 6,2 & 3,3 & - & 54 & 30 & - & 85 \\
\hline 3 & 130,3 & 129,5 & 130,1 & 8,1 & 3,3 & 4,8 & 946 & 382 & 561 & 1889 \\
\hline
\end{tabular}


Table 5 - Power consumption disregarding the losses by THDi

\begin{tabular}{|c|c|c|c|c|c|c|c|c|c|c|}
\hline \multirow[b]{2}{*}{$\Phi$} & \multicolumn{3}{|c|}{$\begin{array}{l}\text { Media Voltage } \\
\text { (V) }\end{array}$} & \multicolumn{3}{|c|}{$\begin{array}{c}\text { Current } \\
\text { without } \\
\text { losses } \\
\text { THDi (A) } \\
\end{array}$} & \multicolumn{3}{|c|}{ Power (W) } & \multirow[t]{2}{*}{$\begin{array}{c}\text { Total } \\
\text { Power } \\
\text { (W) }\end{array}$} \\
\hline & A & $\mathbf{B}$ & C & $\mathbf{A}$ & B & C & $\mathbf{A}$ & B & C & \\
\hline 1 & 25,2 & - & - & 1,3 & - & - & 136 & - & - & 136 \\
\hline 2 & 24,2 & 129, & - & 6,2 & 3,2 & - & 541 & 297 & - & 83 \\
\hline 3 & 130,3 & 129,5 & 130,1 & 7,7 & 2,0 & 4,7 & 906 & 237 & 557 & 1700 \\
\hline
\end{tabular}

The following tables (6 and 7) bring (to the three cases) the average active power, the monthly energy consumption, obtained by the product of the average power by the hours of the month (720h), and the cost of electricity for this period, adopting the rate of $\mathrm{R} \$ 045 / \mathrm{Wh}$ for residential consumers of Manaus.

Table 6 - Cost of energy considering the losses by THDi

\begin{tabular}{|c|c|c|c|}
\hline & $\begin{array}{c}\text { TOTAL } \\
\text { POWER } \\
(\mathbf{W})\end{array}$ & $\begin{array}{c}\text { MONTHLY } \\
\text { ENERGY } \\
\text { CONSUMPTION } \\
\text { (kWh) }\end{array}$ & $\begin{array}{c}\text { COST OF } \\
\text { ENERGY } \\
(\mathbf{R} \$)\end{array}$ \\
\hline $\mathbf{1}$ & 136,8 & 98,50 & 44,32 \\
\hline $\mathbf{2}$ & 852,3 & 613,66 & 276,15 \\
\hline $\mathbf{3}$ & 1888,8 & 1359,94 & 611,97 \\
\hline
\end{tabular}

Table 7 - Cost of energy losses by disregarding THDi

\begin{tabular}{|c|c|c|c|}
\hline & $\begin{array}{c}\text { TOTAL } \\
\text { POWER } \\
(\mathbf{W})\end{array}$ & $\begin{array}{c}\text { MONTHLY } \\
\text { ENERGY } \\
\text { CONSUMPTION } \\
\text { (kWh) }\end{array}$ & $\begin{array}{c}\text { COST OF } \\
\text { ENERGY } \\
(\mathbf{R} \$)\end{array}$ \\
\hline $\mathbf{1}$ & 135,7 & 97,70 & 43,97 \\
\hline $\mathbf{2}$ & 837,9 & 603,29 & 271,48 \\
\hline $\mathbf{3}$ & 1700,5 & 1224,36 & 550,96 \\
\hline
\end{tabular}

It is possible to realize the reduction of energy consumption when you remove the total harmonic distortion of current caused by own loads of consumers. Whereas the residential consumer presents the profile of average power consumption in accordance with the data of possession of equipment and usage habits of PROCEL2007, and whereas the total number of residential consumers and the respective standard connection to the electrical network in Manaus, we suggest the estimated extrapolation of this survey results for the total residential consumers in the city of Manaus, as shown in Table 8.

Table 8 - Total cost avoided by extracting the losses by harmonic current distortion

\begin{tabular}{|c|c|c|c|c|}
\hline & $\begin{array}{c}\text { CONSUMER } \\
\text { BY } \\
\text { CONNECTION } \\
\text { TYPE(UNIT) }\end{array}$ & $\begin{array}{c}\text { REDUCTION } \\
\text { CONSUMER } \\
\text { (kWh) }\end{array}$ & $\begin{array}{c}\text { TOTAL } \\
\text { REDUCTION } \\
\text { OF } \\
\text { CONSUMPTION } \\
\text { (kWh) }\end{array}$ & $\begin{array}{c}\text { TOTAL } \\
\text { COST } \\
\text { AVOIDED } \\
\text { (R\$) }\end{array}$ \\
\hline $\mathbf{1}$ & 282.235 & 0,8 & 225.788 & 101.605 \\
\hline $\mathbf{2}$ & 87.901 & 10,37 & 911.533 & 410.190 \\
\hline $\mathbf{3}$ & 38.155 & 135,58 & 5.173 .055 & 2.327 .87 \\
\hline
\end{tabular}

\section{Conclusion}

The observation of residential consumers with connections and profiles of different loads, allowed to evaluate, by means of weekly monitoring, as provided by ANEEL, the quality of the electric power received by those consumers. From the point of view of permanent voltage, frequency and voltage harmonics, it was observed that the local dealership complies with the minimum requirements of provision, as defined by ANEEL. However, by observing the current consumed it was noticed the presence of harmonic current distortions, caused by their own payloads installed on each consumer. It should be noted that, as a case study, the work did not provide a full diagnosis of power supply in the city of Manaus. Only the point results of consumers under this study are presented.

Was raised the cost of electric power consumed in each case from the current measured, and we repeat the same calculation for the same current without harmonic distortion. It was possible to estimate the reduction of approximately $0.8 \mathrm{kWh} / \mathrm{month}(\mathrm{R} \$ 0,36)$ for the consumer $1 ; 10.37 \mathrm{kWh} /$ month $(\mathrm{R} \$ 4,67)$ for the consumer 2; and $135.58 \mathrm{kWh} /$ month $(\mathrm{R} \$ 61,01)$ for consumers 3. Considering hypothetically the homogeneity of the consumers' residential standard of the Residential Class-1, represented by the studied cases, it was made an extrapolation of the results to estimate the potential of energy conservation, which could reach $6,310,376 \mathrm{kWh} /$ month. Whereas the tariff applied today for the utility is $\mathrm{R} \$ 0.45 / \mathrm{kWh}$ for the Residential Class-I, the estimated savings would be $\$ 2,839,669$.

\section{References}

[1] ANEEL (Agência Nacional de Energia Elétrica). Procedimentos de Distribuição de Energia Elétrica no Sistema Elétrico Nacional/PRODIST: Módulo 8. Qualidade da Energia Elétrica. Brasília, 2011. Disponível em: www.aneel.gov.br. Acesso em 10 de janeiro de 2012. [2] DUGAN, R. C. et. all. Electrical Power Systems Quality. 2. ed. New York: McGraw-Hill, 2004.

[3] ELETROBRAS AMAZONAS ENERGIA. Relatório de Administração, 2010. Disponível em:

www.amazonasenergia.gov.br. Acesso em 12 de dezembro de 2010.

\section{[4] ELETROBRÁS/PROCEL/EDUCAÇÃO.}

Conservação de Energia: Eficiência Energética de Equipamentos e Instalações. 3 ed. Itajubá: FUPAI, 2006. $597 \mathrm{p}$.

[5] ELETROBRAS Amazonas/ Energia. DI/NT-01 Fornecimento de energia elétrica em tensão secundária de distribuição. AME, 90 p. 2001.

[6] MARTINHO, Edson. Distúrbios da Energia Elétrica. 2a ed. São Paulo: Érica, 2009.

[7] OLIVEIRA, C. G. de. Estudo sobre Conservação de Energia Elétrica e Qualidade de Energia Elétrica. 2009. 37 f. Dissertação (Mestrado). Universidade Estadual de Campinas, Campinas. 2009.

[8] PROCEL. Avaliação do mercado de eficiência energética no Brasil. Pesquisa de posse de equipamentos e hábitos de uso - Classe residencial, Relatório Norte. 2007. 